\begin{tabular}{|l|l|}
\hline Суб’єктивні & \multicolumn{1}{|c|}{ Об’єктивні } \\
\hline & рівень якісних характеристик тестових завдань \\
\hline & якість формулювання інструкції до тестових завдань \\
\hline & $\begin{array}{l}\text { відповідність типу та виду тестових завдань методам і } \\
\text { прийомам навчання }\end{array}$ \\
\hline & рівень розвитку спеціальних умінь виконувати тест \\
\hline & фізичні умови тестування \\
\hline & рівень професійної підготовки розробника тесту \\
\hline
\end{tabular}

Отже, серед наявних засобів діагностики базових знань у фармацевтичних вищих навчальних закладах найбільш прогресивною та об'єктивною в сучасних умовах уважається тестування.

Водночас не підлягає сумніву ефективність тестування як оптимальної форми експрес-оцінювання базових знань майбутніх фармацевтів. Аналіз зарубіжної літератури свідчить, що східноєвропейські вищі навчальні заклади не відмовляються від прогресивних форм контролю навчання: це практичний контроль навичок та вмінь, це захист контрольних, курсових, дипломних, магістерських робіт тощо.

На сучасному етапі більшість фармацевтичних факультетів працює в інноваційному режимі. Тому сучасні засоби діагностики якості навчальних досягенень у системі фармацевтичної освіти мають розглядатися 3 урахуванням принципових змін, що відбуваються у зв'язку із реалізацією нового етапу реформування вищої фармацевтичної освіти України.

Аналіз наукових праць засвідчує відсутність дидактичних i методичних засад професійної підготовки майбутніх фармацевтів. Водночас у нових умовах саме такі засади стануть науковою базою для розв'язання цілої низки питань, що дозволить здійснювати цілеспрямовану орієнтацію в засвоєнні базових знань майбутніми фармацевтам та оволодінні ними професійними вміннями і навичками, які забезпечать гарантований розвиток і становлення особистості у фармацевтичній галузі.

\title{
Література
}

1. ВОЗ о роли фармацевта [Электронный ресурс]. - Режим доступа: http://www. apteka.ua/article/12892 2. Волох Д. С. Фармацевтична освіта сьогодні в Україні : традиції, сьогодення, майбутнє [Електронний ресурс]/ Д.В. Волох. - Режим доступу : http://www. apteka.ua/article/14237 3. Державна національна програма «Освіта: Україна XXI століття». Київ : Райдуга, 1994. 4. Майоров А. Н. Элементы педагогического мониторинга и региональных стандартов в управлении / А. Н. Майоров, Л. Б. Сахарчук, А. В. Сотов. Санкт-Петербург, 1992.-316 с. 5. Фармацевтична освіта України. Роль та завдання самостійної роботи : [навч.-метод. посіб.] / В. П. Черних, В. М. Толочко, В. А. Георгінц та ін. ; за ред В.П. Черних. - Харків : НфаУ: Золоті сторінки, 2003. - 96 с. 6. Фокус на пациента. Стратегия реформы фармацевтического сектора в Нових Независимых государствах / EUR / ISP / QCPH062202 WHO/DAP/98. 8. - Москва, 1998. - 39 с. 7. Черних В. П. Моніторинг якості навчання в Національному фармацевтичному університеті / В. П. Черних, І. С. Гриценко. - Харків: НФаУ, - 2007. - 18 с. 8. Quality education and competencies for life / Workshop 3 / Background Paper-2004. - P. 16.

УДК 371.134

Оксана Гриджук

\section{КОМПОНЕНТИ ТЕРМІНОЛОГІЧНОЇ КОМПЕТЕНТНОСТІ СТУДЕНТІВ ЛІСОТЕХНІЧНИХ СПЕЦІАЛЬНОСТЕЙ}

Гриджук О. С. Компоненти термінологічної компетентності студентів лісотехнічних спеціальностей.

У статті розкрито сутність понять термінологічна культура, термінологічний 
потенціал особистості, термінологічна компетентність та окреслено їх компоненти, необхідні для навчання майбутніх фахівців лісопромислового комплексу. Названо ознаки сформованої термінологічної культури фахівця, про належний рівень якої можна говорити лише за умови повного використання термінологічного потенціалу особистості. У термінологічному потенціалі майбутнього фахівця виокремлено три рівні: рівень термінологічної обізнаності; рівень термінологічної грамотності; рівень термінологічної компетентності. Термінологічна компетентність розглядається як складник мовнокомунікативної компетентності студентів.

Ключові слова: термінологічна культура, термінологічний потенціал особистості, термінологічна обізнаність, термінологічна грамотність, термінологічна компетентність.

Гриджук О. Е. Компоненты терминологической компетентности студентов лесотехнических специальностей.

В статье раскрыта сущность понятий терминологическая культура, терминологический потенциал личности, терминологическая компетентность, определены их компоненты, необходимые для обучения будущих специалистов лесопромышленного комплекса. Названы признаки сформированной терминологической культуры специалиста, о надлежащем уровне которой можно говорить лишь при условии полного использования терминологического потенциала личности. В терминологическом потенциале будущего специалиста выделены три уровня: уровень терминологической осведомленности; уровень терминологической грамотности; уровень терминологической компетентности. Терминологическая компетентность рассматривается как составляющая языковой и коммуникативной компетентности студентов.

Ключевые слова: терминологическая культура, терминологический потенциал личности, терминологическая осведомлённость, терминологическая грамотность, терминологическая компетентность.

Hrydzhuk O. Ye. The components of terminological competence of students of forestry specialties.

The problem of creating an integrated system of formation of terminological competence of students of Forestry field at the present stage acquires the special actuality.

Mastering special terminology is the basis for the formation of professional speech of specialist of any profile.

The essence of the concepts of terminological culture, terminological potential of personality, terminological competence is revealed, their components needed for training of future professionals of the forestry industry are outlined.

The features of formed terminological culture of specialist are named, including the following:

1) studying the vocabulary of professional terminology; 2) possession of skills to work effectively with scientific sources; 3) the ability to analyze the terms concerning their origin, structure, method of creation, normativity, the degree of mastering the language, etc.; 4) the ability to detect errors and flaws in the use of terms and remove them; 5) the ability to distinguish between productive and unproductive patterns of creating terms, use them for the creation or improvement of terminological material.

We can consider the appropriate level of specialist terminological culture only with the full use of terminological potential of personality.

There are three levels in terminological potential of future specialist such as: terminological awareness level, terminological literacy level and terminological competence level.

We understand the concept of terminological competence as the capability of specialist to use professional terms in the scientific and professional activities that may be achieved through the acquisition of the system of the special knowledge, cognitive abilities and practical skills.

The close cooperation of experts and linguists is the condition for the effective formation of terminological competence. 
Terminological competence is seen as a part of language and communicative competence of students.

Key words: terminological culture, terminological potential of personality, terminological awareness, terminological literacy, terminological competence.

Орієнтація навчального процесу у вищій школі на формування ключових компетентностей зумовила потребу в удосконаленні змісту навчальних дисциплін, посиленні практичного спрямування освіти, актуалізації значущості комунікативної підготовки студентів. «Мовна освіта нині - основа формування пізнавально-творчої особистості, що володіє високим рівнем комунікативної компетентності, здатна до сприйняття і передавання різноманітної інформації» [8, с. 123].

Удосконалення мовної освіти у сучасному вищому навчальному закладі лісотехнічного профілю залишається нагальним, оскільки саме завдяки розвиненим мовнокомунікативним навичкам студент як майбутній спеціаліст зможе належно виконувати свої професійні обов'язки, налагоджувати ділові стосунки, долати різноманітні бар'єри, що перешкоджають якісному спілкуванню у виробничих обставинах. Від опанування «наукового дискурсу професії» [12, с. 64], тобто формування термінологічної компетентності, залежатиме ефективність фахівця на сучасному ринку праці.

У сучасній лінгводидактиці недостатньо вивченими залишаються питання, пов'язані зі з'ясуванням сутності термінологічної компетентності (ТК) та їі формування у студентів технічних спеціальностей. Лише окремі аспекти розвитку ТК розглянуто у працях Н. Бондаренко, Т. Денищич, Е. Огар, Т. Симоненко, Т. Стасюк. Проблему формування професійно-термінологічної компетентності у процесі вивчення фахових дисциплін досліджували Т. Бутенко, Л. Вікторова, І. Власюк.

Мета статті- розкрити сутність поняття термінологічна компетентність, окреслити іï компоненти, необхідні для навчання української мови за професійним спрямуванням майбутніх фахівців лісопромислового комплексу i формування їхньої термінологічної культури.

Основою для формування професійного мовлення спеціаліста будь-якого профілю $є$ опанування фаховою термінологією, причому не лише на рівні семантики термінів (засвоєння їх значень), а й умілого граматично та стилістично виправданого їх використання.

Процес розвитку й удосконалення термінологічних умінь і навичок студентів у вищій школі має грунтуватися на таких принципах: забезпечення безперервної освіти; орієнтації вищої освіти на розвиток мовної особистості майбутнього спеціаліста; раціонального застосування сучасних методів та засобів навчання на різних етапах підготовки майбутніх фахівців; інформатизації, технічного та технологічного забезпечення, що впливає на розвиток творчого потенціалу студента, його здібностей до комунікативних дій, підвищує інформаційну культуру кожного студента; відповідності результатів підготовки спеціалістів вимогам, що висуваються конкретною сферою їхньої професійної діяльності, або принцип компетентності (на сучасному етапі це забезпечується введенням компетентнісного підходу до навчання) [4].

Засвоєння фахової термінології, розвиток наукового і професійного мовлення - базові компоненти, відсутність яких унеможливлює становлення термінологічної культури студента.

Сутність термінологічної культури Е. Огар трактує як «комплекс мовних i мовленнєвих знань, умінь і навичок фахівця, за допомогою яких формується фундамент теорії і практики фаху, які необхідні для глибшого осмислення й засвоєння його поняттєвої і категоріальної бази, для реалізації найрізноманітніших актів дослідницького, творчоаналітичного та практичного характеру, які формують здатність фахівця-мовця до самостійного термінотворення і терміноупорядкування» [7].

Ознаками сформованої термінологічної культури фахівця є: «1) володіння термінним словником, постійне його поповнення; 2) володіння навичками ефективної роботи 3 
джерелами, необхідними для розв'язання завдань лінгвістичного i термінознавчого характеру; 3) уміння аналізувати термінний матеріал щодо його походження, структури, способу творення, нормативності, ступеня засвоєння мовою, актуальності та ін.; 4) уміння виявляти на основі попередньо описаних знань помилки і вади в терміновживанні i, відповідно, усувати їх; 5) уміння розрізняти продуктивні й непродуктивні моделі термінотворення, використовувати їх для творення чи вдосконалення термінного матеріалу» [7].

Про належний рівень термінологічної культури фахівця можна говорити лише за умови повного використання термінологічного потенціалу особистості, що «являє собою сукупність властивостей ..., які надають можливість успішно засвоювати навчальний матеріал, певні соціокультурні норми, набувати професійного досвіду i сприяють саморозвитку особистості» [3]. У термінологічному потенціалі спеціаліста дослідники виокремлюють три рівні: рівень термінологічної обізнаності; рівень термінологічної грамотності; рівень термінологічної компетентності [6;3].

Термінологічна обізнаність «виникає на початковому етапі вивчення дисциплін» [3], коли формуються загальні уявлення про фахові терміни, виникає розуміння термінології як системи спеціальних понять.

Під поняттям термінологічна грамотність Г. Бондаренко розуміє «відповідність ужитих студентами термінолексем орфографічним нормам української мови (для писемного мовлення), граматичним законам словозміни (для усного й писемного мовлення), нормам української орфоепії (для усного мовлення)» [1, с. 11].

До трактування поняття «термінологічна компетентність» науковці підходять порізному. Т. Симоненко характеризує ТК як «інтегральну характеристику ділових i особистісних якостей людини, що відображає не тільки рівень знань, умінь і навичок, достатніх для досягнення цілей професійної діяльності, але й високу соціально-моральну позицію професіонала» [11, с. 131].

За Г. Бондаренко, ТК - це «вміння добирати терміни відповідно до теми висловлювання, ураховувати відмінності паронімічних термінів, не допускати заміни однієї термінологічної одиниці іншою, уживати терміни відповідно до їх дефініції, розрізняти терміни та професіоналізми, відрізняти економічні терміни від термінів інших галузей знань, нормативно перекладати економічні терміни й термінологічні словосполучення українською мовою» [1, c. 11].

Т. Денищич убачає у ТК «здатність людини розуміти й породжувати професійні висловлювання в різноманітних соціально-детермінованих ситуаціях 3 використанням фахової лексики та з урахуванням лінгвістичних і соціальних правил, яких дотримуються носії мови» [5, с. 138].

Л. Вікторова трактує поняття професійно-термінологічної компетентності як складник професійної компетентності і вважає, що вона «відображає готовність і здатність фахівця демонструвати належні особистісні якості в ситуаціях професійного спілкування, мобілізуючи для цього знання фахової термінології, вміння та навички використовувати 3 точністю i лінгвістичною правильністю терміни в усному i писемному професійному мовленні відповідно до нормативних вимог» [2, с. 7]. «Більш грунтовно зміст професійнотермінологічної компетентності відображають іiі функції: інформаційно-комунікативна, аналітико-конструктивна, діяльнісно-регулятивна, формувально-розвивальна та профілактико-виховуюча» [2, с. 8].

Термінологічна компетентність - здатність фахівця послуговуватися фаховими термінами у процесі наукової та професійної діяльності, що може бути досягнута через набуття системи спеціальних знань, когнітивних умінь i практичних навичок; ТК $\epsilon$ компонентом мовнокомунікативної компетентності студентів.

До системи спеціальних відносимо знання з предметної сфери (фахові, технічні та екологічні) та лінгвістичні знання (мовні та комунікативні), зокрема: закономірності та специфіка розвитку термінології лісівництва та деревооброблення; аналіз складу і системної 
організації української термінології лісотехнічної галузі; характерні ознаки та вимоги до термінів, специфіка використання термінів у діловому мовленні; способи номінації спеціальних понять; лексико-генетичні особливості лісівничої термінології; специфіка лексико-семантичних процесів у терміносистемах лісівництва та деревооброблення; способи творення термінів лісівництва; жанри наукових текстів, особливості їх створення; загальні та галузеві словники; теоретичні засади стандартизації й уніфікації термінологічних одиниць; 3'ясування способів фіксації термінів у словниках; збагачення фахового словника студента (шляхом засвоєння термінів-синонімів, розмежування семантики багатозначних термінів, термінів-паронімів і термінів-омонімів, обізнаність із діалектними найменуваннями спеціальних понять тощо).

До когнітивних передусім належать уміння, що забезпечують організацію власної пізнавальної діяльності, а саме: правильно використовувати фахові терміни; аналізувати фахові терміни в лінгвістичному аспекті; орієнтуватися в лексико-семантичних процесах, що стосуються термінології обраного фаху: ураховувати специфіку використання багатозначних термінів, доцільність чи недоцільність використання термінів-синонімів, паронімів; складати нормативні наукові тексти зі спеціальності, аналізувати їх щодо правильності побудови, логіки викладу інформації; редагувати наукові тексти: виявляти й виправляти лексичні, стилістичні, граматичні, синтаксичні недоліки, орфографічні та пунктуаційні помилки; перекладати фахові тексти; користуватися лінгвістичними та спеціальними словниками як довідковими джерелами; творчо розв’язувати запропоновані викладачем проблемні завдання.

Практичні навички трактуємо як дії, що внаслідок багаторазових повторень доведені до високого рівня досконалості й виконуються на частково автоматизованому рівні [9]. Такі навички передбачають не лише вправне послуговування фаховою термінолексикою, а й: усвідомлене використання спеціальних найменувань відповідно до норм сучасної української літературної мови, здійснення таким чином наукового та виробничого спілкування; мовностилістичний аналіз наукового тексту; створення, редагування та переклад наукових текстів у галузі лісівництва та деревооброблення; належний рівень усного наукового мовлення; осмислення й критичний аналіз власних і чужих висловлювань; виконання навчальних завдань проблемно-пошукового характеру.

Формування термінологічної компетентності- це процес, що триває впродовж навчання студента у ВНЗ. На таку властивість компетентностей указує Ю. Рашкевич, зазначаючи, що однією з особливостей «компетентностей є те, що їх набувають поступово; вони формуються цілою низкою дисциплін або модулів на різних етапах даної програми, а можуть навіть починати формуватися в рамках програми одного рівня вищої освіти, а закінчувати формування на іншому, вищому рівні» [10, с. 30].

Тому важливим, на наш погляд, є розуміння того, що говорити про сформовану термінологічну компетентність лише як результат вивчення спеціальних дисциплін не $\epsilon$ доцільним. Умовою ефективного формування термінологічної компетентності $\epsilon$ тісна співпраця фахівців і філологів у контексті поєднання спеціальних та мовних знань, а отже, взаємозв'язку фахової та лінгвістичної підготовки студентів. Це процес, що відбувається поступово в кількох основних напрямках: це поступове засвоєння спеціальної термінолексики, вивчення мови професійного спрямування (у межах дисципліни «Українська мова за професійним спрямуванням»), опрацювання теоретичних засад термінознавства (у межах курсу «Фахова термінологія»).

Діапазон фахових знань за такого підходу $є$ достатньо широким: від засвоєння базових термінологічних понять до сприйняття термінології фаху як цілісної, ієрархічно організованої системи; до розв'язання практичних завдань українського термінознавства систематизації, упорядкування та стандартизації фахових термінів.

Метою такого навчання має стати формування у студентів лісотехнічних спеціальностей цілісної системи фахових і лінгвістичних знань, що забезпечить належний рівень їхньої професійної комунікації в майбутній трудовій діяльності. Перспективи подальших досліджень убачаємо у створенні навчального контенту курсу «Фахова 
термінологія» для студентів спеціальностей «Лісове господарство» та «Деревооброблювальні технології».

\section{Література}

1. Бондаренко Г. П. Методика навчання студентів економічних спеціальностей української наукової термінології в умовах східного регіону України : автореф. дис. на здобуття наук. ступеня канд. пед. наук : спец. 13.00.02 «Теорія і методика навчання української мови» / Г. П. Бондаренко. - Київ, 2008. - 21 с. 2. Вікторова Л. В. Формування професійно-термінологічної компетентності студентів вищих аграрних навчальних закладів у фаховій підготовці : автореф. дис. на здобуття наук. ступеня канд. пед. наук : спец. 13.00.04 «Теорія i методика професійної освіти»/ Л. В. Вікторова. - Чернігів, 2009. - 23 с. 3. Денищич T. Спеціальні та власне методичні принципи формування термінологічної компетентності майбутніх соціологів [Електронний ресурс] / Т. Денищич // Збірник наукових праць Уманського державного педагогічного університету. - 2014. - Ч. 2. - С. 113-120. Режим доступу до докум. : http://nbuv.gov.ua/ UJRN/znpudpu_2014_2_17. 4. Денищич Т. А. Формування термінологічної компетентності майбутніх фахівців 3 політології [Електронний pecypc] / Т. А. Денищич // Наукові праці [Чорноморського державного університету імені Петра Могили комплексу «Києво-Могилянська академія»]. Сер. : Педагогіка. - 2012. T. 209. - Вип. 197. - С. 137-142. - Режим доступу до докум. : http://nbuv.gov.ua/UJRN/ Npchduped_2012_209_197_28. 5. Ермолаева Ж. Е. О формировании терминологической культуры обучающихся в вузах МЧС России / Ж. Е. Ермолаева // Технологии техносферной безопасности. - 2014. - Вып. № 5 (57). - Режим доступа к докум. : http://ipb.mos.ru/ttb/20145/2014-5.html. 6. Огар Е. I. Українська видавнича термінологія : нормалізаційні та функціональні аспекти [Електронний ресурс] / Е. І. Огар.- Режим доступу до докум. : http://journlib.univ.kiev.ua/index.php?act=article\&article=2399. 7. Пентилюк М. Розвиток української лінгводидактики в контексті державного стандарту базової і повної освіти в Україні / М. Пентилюк. - Вісник Львів. університету. Серія філологічна. - 2010. - Вип. 50. С. 123-130. 8. Психологічна енциклопедія / авт.-упор. О. М. Степанов. - Київ : Академвидав, 2006. - 424 с. 9. Рашкевич Ю. М. Болонський процес та нова парадигма вищої освіти: [монографія] / Ю. М. Рашкевич. - Львів : Видавництво Львівської політехніки, 2014. - 168 с. 10. Симоненко Т. В. Теорія i практика формування професійної мовнокомунікативної компетенції студентів філологічних факультетів : [монографія] / Т. В. Симоненко. - Черкаси, 2006. - 328 с. 11. Тоцька Н. Методика роботи викладачів вищого технічного навчального закладу над українським професійним мовленням студентів / Н. Тоцька // Дивослово. 2003. - № 1. - С. 62-65.

УДК 378.1:687

Вікторія Желанова

\section{КОНТЕКСТУАЛІЗАЦІЯ ПРОФЕСІЙНОЇ ПІДГОТОВКИ ДИЗАЙНЕРІВ ОДЯГУ У ВНЗ}

\footnotetext{
Желанова В. В. Контекстуалізація професійної підготовки майбутніх дизайнерів одягу у ВНЗ.

У представленій статті розглянуто принцип контекстуалізації у форматі професійної підготовки дизайнерів одягу у ВНЗ. Висвітлено концептуальні засади контекстуалізації професійної підготовки майбутніх дизайнерів одягу. Подано дефініції поняття «контекстний підхід», «контекст», «професійний контекст». Обгрунтовано феномен «професійний контекст майбутнього дизайнера одягу» й розглянуто його структуру, що містить мотиваційноціннісний, творчо-проектувальний, виробничий контексти. Розкрито змістову площину контекстуалізації. Проаналізовано організаційні аспекти контекстуалізації, що пов’язані 3 упровадженням певного педагогічного інструментарію контекстної спрямованості.
} 